\title{
Occurrence and Characterization of Extended Spectrum $\beta$ - lactamase Producing $E$. coli and Salmonella spp. from Raw Milk Samples in Wayanad District, Kerala, India
}

\author{
K. L. Akarsh ${ }^{2 *}$, Prejit ${ }^{1,2}$, K. Asha ${ }^{2}$, Jess Vergis ${ }^{2}$, V. K. Vinod ${ }^{2}$ and Hema Persis Andrews ${ }^{2}$ \\ ${ }^{1}$ Centre for One Health Education, Advocacy, Research and Training, \\ ${ }^{2}$ Department of Veterinary Public Health, CV\&AS, Kerala Veterinary and Animal Sciences \\ University, Pookode, Wayanad-673576, India
}

*Corresponding author

\section{A B S T R A C T}

\section{Keywords}

E. coli, Salmonella spp., Raw milk,

ESBL, uidA, invA blaTEM, blaCTX$\mathrm{M}$, blaSHV

Article Info

Accepted:

15 November 2019

Available Online:

10 December 2019
Escherichia coli and Salmonella are considerably responsible for causing gastrointestinal disorders. Emergence of Extended spectrum beta lactamase (ESBL) production among the above organisms is a great matter of concern. Hence, the present study is envisaged to know the distribution status of ESBL producing E. coli and Salmonella spp. from raw milk samples. A total of 50 raw milk samples was collected and were analyzed for the E. coli and Salmonella through conventional culture method and confirmation by PCR using uidA gene (E. coli) and invA gene (Salmonella). The occurrence of E. coli and Salmonella spp in raw milk was found to be 60 per cent and 18 per cent, respectively Further, characterization of isolates for phenotypic ESBL production revealed that 21 E. coli (70\%) and 7 Salmonella $(77.77$ $\%)$ as phenotypic ESBL producers and were resistant to third generation cephalosporins. blaTEM, blaCTX-M and blaSHV gene was present in 56.66 per cent, 40 per cent and 26.66 per cent of the E. coli isolates and the occurrence of blaSHV, blaCTX-M and blaTEM gene in Salmonella isolates was 55.5 percent, 44.4 per cent and 11.1 per cent, respectively. Thus the present study envisaged the need of hygienic milk production and proper antibiotic usage to prevent further spillover of resistant pathogenic organisms among public and environment.

\section{Introduction}

Milk is a highly nutritious food. However, it acts as a good medium for the growth of different microorganisms which cause spoilage of milk leading to severe infections in humans (Murinda et al., 2004). Generally contamination of milk occurs through colonization of teat canal by various pathogenic microorganisms like E. coli and Staphylococcus aureus which are commonly present in environment or might be due to 
external contamination from milkers hand, external environment and water used during milking (Thaker et al., 2012). Contamination of raw milk with Salmonella organism is attributed to faecal contamination by infected animals, contaminated utensils or through contaminated water. There are some consumers who prefer raw milk and their products over pasteurized milk for consumption which can be a major public health concern if the milk gets contaminated (Chye et al., 2004).

Indiscriminate use of antibiotics without antibiotic sensitivity test and misuse of antibiotics has led to the development of resistance to commonly used antibiotics among micro organisms which are shedding out through milk (Owens et al., 1997).

Salmonella and pathogenic strain of E. coli are the leading cause of food borne zoonosis annually worldwide which spreads even through contaminated milk have acquired antibiotic resistance to commonly used antibiotics including third generation cephalosporins (Levy, 1997). From past 2 decades, Extended spectrum beta lactamases resistance has spread among pathogenic microorganisms all over the world which are having ability to hydrolyze newer antibiotics even third generation cephalosporins (ceftriaxone, cefotaxime, ceftazidime) and monobactams (aztreonam). Thus the study was envisaged to know the occurrence of ESBL producing E. coli and Salmonella organisms and their resistance pattern to various antibiotics from raw milk samples in Wayanad district.

\section{Materials and Methods}

\section{Sample collection}

A total of 50 raw milk samples were collected from milk societies and dairy farmers of
Vythiri, Sulthan bathery and Mananthavady taluks of Wayanad district, Kerala. Samples were collected in sterile test tubes with screw capped and transported to laboratory in refrigerated condition.

\section{E. coli and Salmonella isolation by culture method}

Isolation of E. coli and Salmonella was carried out as per the standard protocol described by Agarwal et al., (2003) and Barrow and Feltham (2003). Pre enrichment of the samples was done in Buffered peptone water, followed by enrichment at the rate of 1:10 dilution in nutrient broth for $E$. coli and selenite broth for Salmonella. This was followed by selective plating onto EMB agar (E. coli) and on $\mathrm{HE}$ agar (Salmonella). On EMB agar black/purple colonies with green metallic sheen were presumptively identified to be $E$. coli and black colour colonies with narrow green margin were presumptively identified as Salmonella. All the above mentioned colonies were subjected to biochemical tests for confirmation as per the procedure described by Barrow and Feltham (2003) and Agarwal et al., (2003) by performing primary, secondary (IMViC test) and other tertiary biochemical tests (Fig. 1 and 2).

\section{Molecular confirmation of $E$. coli and Salmonella}

E. coli and Salmonella isolates obtained from culture method were confirmed by PCR targeting $u i d \mathrm{~A}$ gene and invA gene, respectively. The primer details and cyclic condition of both genes are provided in Table 1 and 2.

Phenotypic and genotypic characterization of isolates for ESBL production

The antibiotic susceptibility testing of confirmed isolates of E. coli and Salmonella 
was carried out as per the guidelines provided by Clinical Laboratory Standards Institute (2018). Escherichia coli ATCC 25922 was used as the quality control strain. Commercial antibiotic discs, Aztreonam (30 $\mu \mathrm{g})$, Ceftriaxone (30 $\mu \mathrm{g})$, Cefotaxime (CTX 30 $\mu \mathrm{g}$ ), Ceftazidime (CAZ 30 $\mu \mathrm{g}$ ), Ceftazidime/ Clavulanic acid (CAC 30/10 $\mu$ g), Cefoxitin $(30 \mu \mathrm{g})$ and Imipenem $(10 \mu \mathrm{g})$ (HiMedia Laboratories Ltd, Mumbai) were used in the study. Isolates were screened for ESBL production based on standard disc diffusion method as per Nagdeo et al., (2012).

Briefly, sterile cotton swab was used to inoculate pure culture of test isolate (equivalent to 0.5 Mcfarland approximately $1.5 \times 10^{8} \mathrm{CFU} / \mathrm{ml}$ ) evenly on Muller-Hinton (MH) agar. Antibiotic discs were placed on inoculated $\mathrm{MH}$ agar and incubated for overnight incubation at $37{ }^{\circ} \mathrm{C}$. The zone of inhibition diameter was measured for each antibiotic and was compared with interpretative chart furnished by the manufacturer to grade the test isolates as sensitive, intermediate and resistant for respective antibiotics.

Genotypic characterization of the isolates by PCR targeting ESBL producing genes

PCR was standardized for characterization of the positive E. coli and Salmonella isolates for presence of ESBL producing genes. The details of the ESBL genes blaCTX-M, blaSHV and blaTEM are mentioned in Table 1.

PCR condition for ESBL genes involved the following steps, initial denaturation at $94^{\circ} \mathrm{C}$ for 5 min followed by 35 cycles each of denaturation at $94{ }^{\circ} \mathrm{C}$ for $1 \mathrm{~min}$, annealing at $56{ }^{\circ} \mathrm{C}$ for $1 \mathrm{~min}$, extension at $72{ }^{\circ} \mathrm{C}$ for $1 \mathrm{~min}$ and final extension at $72{ }^{\circ} \mathrm{C}$ for $5 \mathrm{~min}$. Automated thermal cycler (Bio-Rad, USA) was used to carry out the PCR reactions.

\section{Results and Discussion}

Occurrence of $E$. coli and Salmonella isolates from raw milk samples

In the present study occurrence of E. coli organism from raw milk samples collected from various taluks of Wayanad district was found to be 60 per cent ( 30 numbers) which is in accordance with the results obtained by Ali and Abdelgadir (2011) where the prevalence rate was 63 per cent. In contrast, a lower prevalence rate was recorded in the studies conducted by Thaker et al., (2012) (38 per cent) and by Kumar and Prasad (2010) (6.66 per cent). Hence, contamination of milk with E. coli is comparatively higher in Wayanad district which emphasize the need to adopt hygienic practices at farms. The higher occurrence rate of $E$. coli further emphasizes the need to adopt strict hygienic measures at milk production and collection units including its transportation. There is a need to educate farmers on environmental contamination at cattle shed, hygienic milkers and milking practice, health animal/ udder and clean milk vessels. The prevalence rate of Salmonella among the collected raw milk samples was 18 per cent which is in accordance with the findings of Tadesse and Dabassa (2012) where the prevalence rate was 20 per cent. In contrary lower prevalence was observed by Karns et al., (2005) (2.6 per cent) and Kaushik et al., (2014) (5.6 per cent). The finding of a higher occurrence rate in our study might be because of external faecal contamination or by the usage of contaminated water at the time of milking.

Phenotypic characterization of $E$. coli and Salmonella isolates for ESBL production by disc diffusion method

A total of 30 E. coli and 9 Salmonella isolates were isolated from raw milk samples analyzed. Among them 21 E. coli $(70 \%)$ and 7 
Salmonella $(77.77 \%)$ isolates were found positive for phenotypic ESBL production where they exhibited resistance to cefotaxime and ceftazadime. Antibiotic susceptibility testing revealed that E. coli isolates showed more resistance to third generation cephalosporins like cefotaxime $(60.00 \%)$ and ceftazadime $(46.66 \%)$. They were more susceptible to antibiotics imipenum (76.66\%), aztreonam $(60.00 \%)$, ceftazadime/clavulanic acid (56. 66\%) and ceftriaxone (46.66\%) in descending order. Olowe et al., (2015) in his research identified 63.2 per cent of the $E$. coli isolates as phenotypic ESBL producers which is similar to the results of present study. However, lesser prevalence rate was observed by Sharma et al., (2013) in Jaipur (52.49 per cent). Salmonella isolates were more susceptible to imipenum (77.77\%), ceftazadime/clavulanic acid (66.66\%), ceftriaxone $(55.55 \%)$ and aztreonam $(44.44 \%)$ in descending order. They showed more resistance to cefotaxime $(66.66 \%)$ and ceftazadime (33.33\%). Higher isolation rate of ESBL producing Salmonella isolates were observed in the present study compared to Yang et al., (2012) where 21.7 per cent of the Salmonella isolates were phenotypic ESBL producers.
Genotypic characterization of $E$. coli and Salmonella isolates for ESBL production

All the phenotypic ESBL producers were examined for the presence of various ESBL genes including blaCTX-M, blaSHV and blaTEM gene. blaTEM was present in 17 $(56.66 \%)$ E. coli isolates, blaCTX-M was present in $12(40.00 \%)$ isolates and blaSHV was less prevalent and detected in $8(26.66 \%)$ isolates. Three E. coli isolates were found to possess all the three bla genes. blaCTX-M and blaTEM together seen in $8 \mathrm{E}$. coli isolates and it is the common combination seen. Hence, the present study showed blaTEM as the most prevalent gene among E. coli isolates in Wayanad district which is similar to the results of Bajpai et al., (2017) where in, blaTEM was the most prominent gene with the prevalence rate of 48.7 per cent followed by blaCTX-M (7.6 per cent) and blaSHV gene (5.1 per cent).

Among nine Salmonella isolates recovered from raw milk samples, five (55.5 per cent) were harboring blaSHV gene, four (44.4 per cent) were harboring blaCTX-M gene and one (11.1 per cent) isolate harbored blaTEM gene (Fig. 3-7).

Table.1 Details of the primer used

\begin{tabular}{|c|c|c|c|}
\hline Target organism & Gene Primer sequence & $\begin{array}{l}\text { Amplic } \\
\text { on size }\end{array}$ & Reference \\
\hline E.coli & $\begin{array}{l}\text { uidA } \mathrm{F}: 5^{1} \text { - TGGTAATTACCGACGAAAACGGC- } 3^{1} \\
\text { R: } 5^{1} \text { - ACGCGTGGTTACAGTCTTGCG-3 }{ }^{1}\end{array}$ & $162 \mathrm{bp}$ & $\begin{array}{l}(\mathrm{Bej}, \\
1991)\end{array}$ \\
\hline Salmonella & 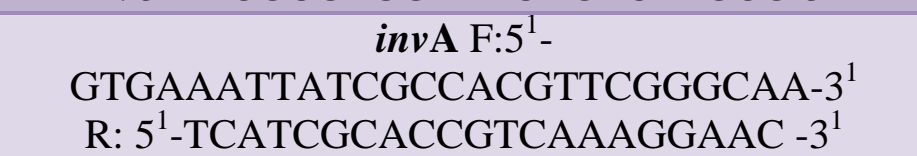 & 284bp & $\begin{array}{l}\text { (Galan et } \\
\text { al., 1992) }\end{array}$ \\
\hline $\begin{array}{c}\text { ESBL producing } \\
\text { Enterobacteriaceae }\end{array}$ & $\begin{array}{l}\text { blaCTX-M F: } 5^{1} \text {-CGCTTTGCGATGTGCAG- } 3^{1} \\
\text { R: } 5^{1} \text {-ACCGCGATATCGTTGGT- }{ }^{1}\end{array}$ & $550 \mathrm{bp}$ & $\begin{array}{l}\text { (Ahmed et } \\
\text { al., 2004) }\end{array}$ \\
\hline & $\begin{array}{l}\text { blaSHV F: } 5^{1} \text { GATGAACGCTTTCCCCATGATG- } 3^{1} \\
\text { R: } 5^{1} \text {-CGCTGTTATCGCTCATGGAA- } 3^{1}\end{array}$ & $214 b p$ & $\begin{array}{l}\text { (Yazdi } e t \\
\text { al., 2012) }\end{array}$ \\
\hline & $\begin{array}{l}\text { blaTEM F: } 5^{1} \text { ATGAGTATTCAACATTTCCG- }{ }^{1} \\
\text { R: } 5^{1} \text {-GTCACAGTTACCAATGCTTA- } 3^{1}\end{array}$ & 847bp & $\begin{array}{l}\text { (Yazdi } e t \\
\text { al., 2012) }\end{array}$ \\
\hline
\end{tabular}


Table.2 PCR cyclic condition for E. coli and Salmonella

\begin{tabular}{|c|c|c|c|c|}
\hline PCR conditions & \multicolumn{2}{|c|}{ uid $\boldsymbol{A}$ gene for $\boldsymbol{E}$. coli } & \multicolumn{2}{c|}{ inv A gene for Salmonella } \\
\hline Process & Temp $\left({ }^{\circ} \mathbf{C}\right)$ & Time & Temp $(\circ \mathbf{C})$ & Time \\
\hline Initial denaturation & 94 & $5 \mathrm{~min}$ & 94 & $5 \mathrm{~min}$ \\
\hline Denaturation & 94 & $40 \mathrm{sec}$ & 94 & $30 \mathrm{sec}$ \\
\hline Annealing & 55 & $60 \mathrm{sec}$ & 55 & $40 \mathrm{sec}$ \\
\hline Extension & 72 & $50 \mathrm{sec}$ & 72 & $50 \mathrm{sec}$ \\
\hline & Repeated cycle of denaturation to extension 35 cycles \\
\hline Final extension & 72 & $5 \mathrm{~min}$ & 72 & $5 \mathrm{~min}$ \\
\hline
\end{tabular}

Fig.1 Salmonella isolates on HE agar (Black colonies with green margin)

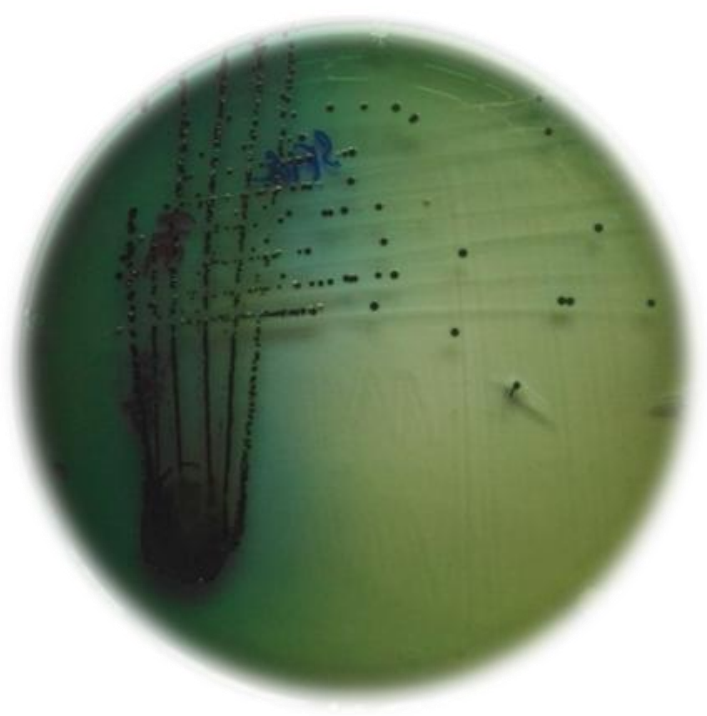

Fig.2 E. coli isolates on EMB agar (Purple colonies with green metallic sheen)

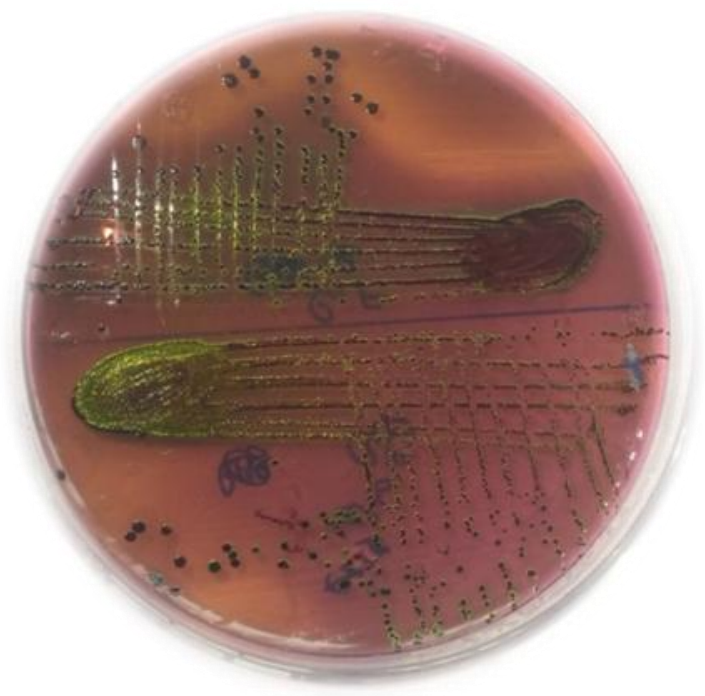


Fig.3 PCR standardization of uidA

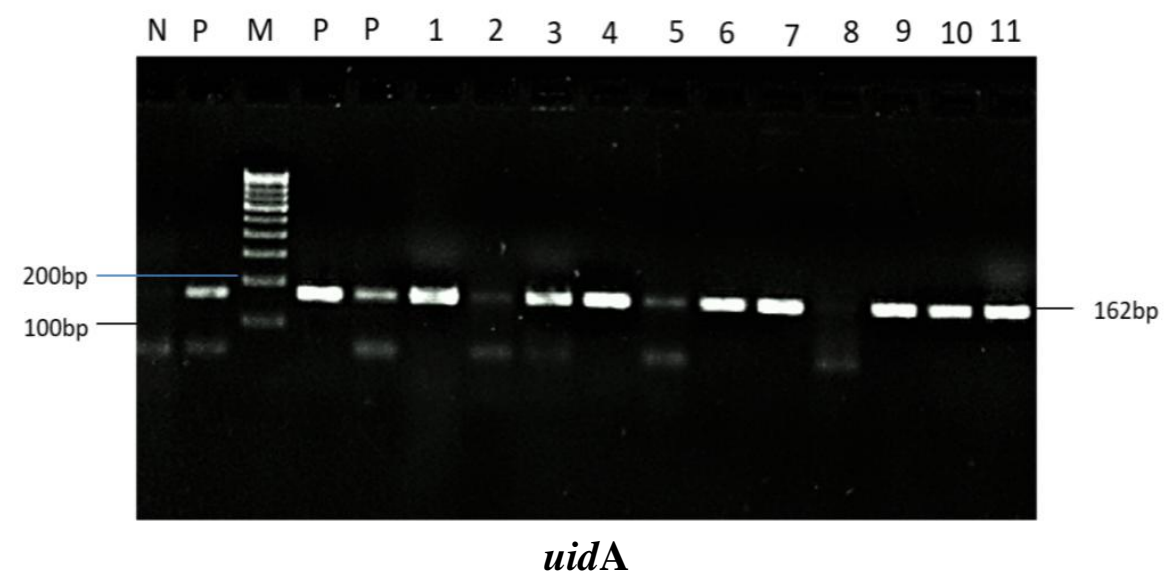

Lane N- Negative control, Lane P- Positive control, Lane M- Marker, Lane 1-11: samples of amplicon size $162 \mathrm{bp}$

Fig.4 PCR standardization of invA

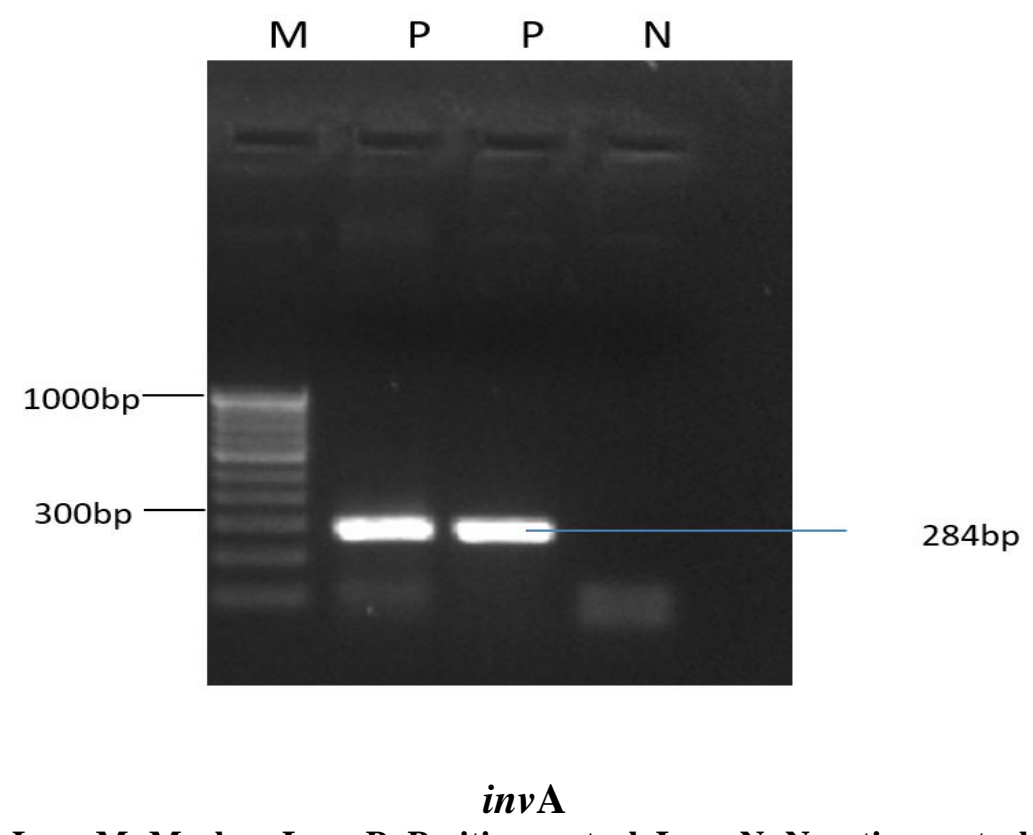

Lane M- Marker, Lane P- Positive control, Lane N- Negative control. 
Fig.5 PCR standardization for blaCTX-M

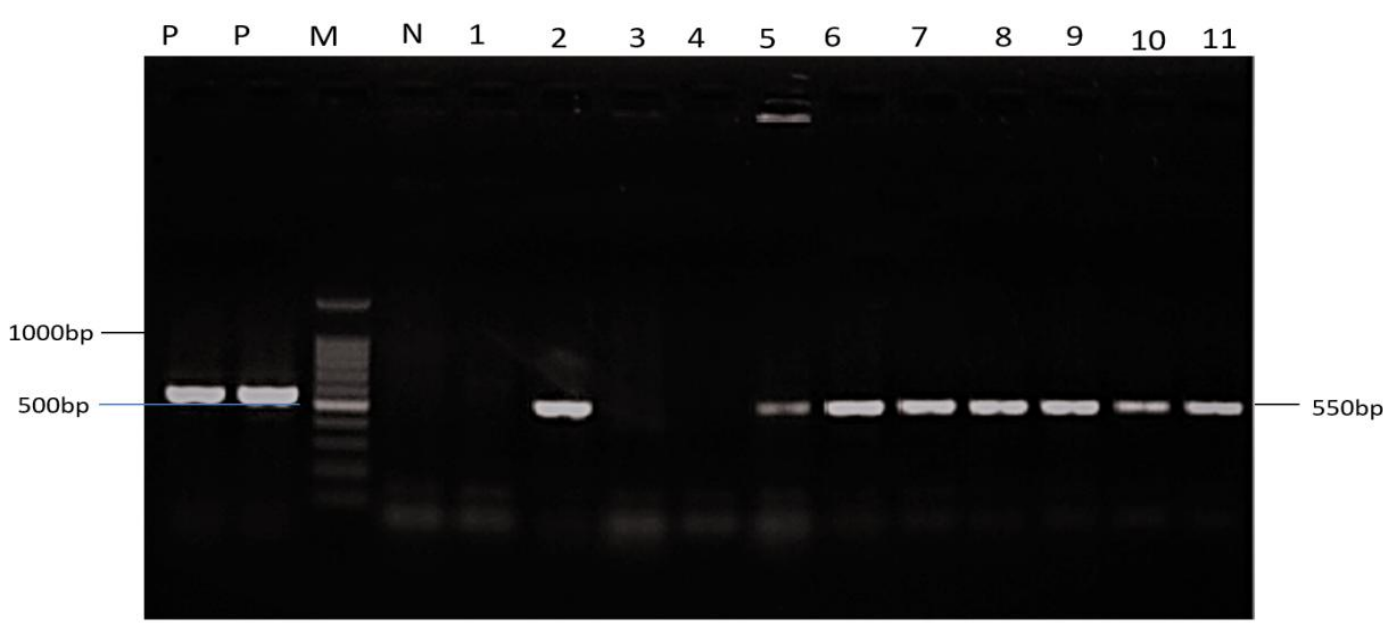

\section{blaCTX-M}

Lane P- Positive control, Lane M- Marker, Lane N- Negative control Lane 1-11: samples of amplicon size $550 \mathrm{bp}$.

Fig.6 PCR standardization for blaSHV

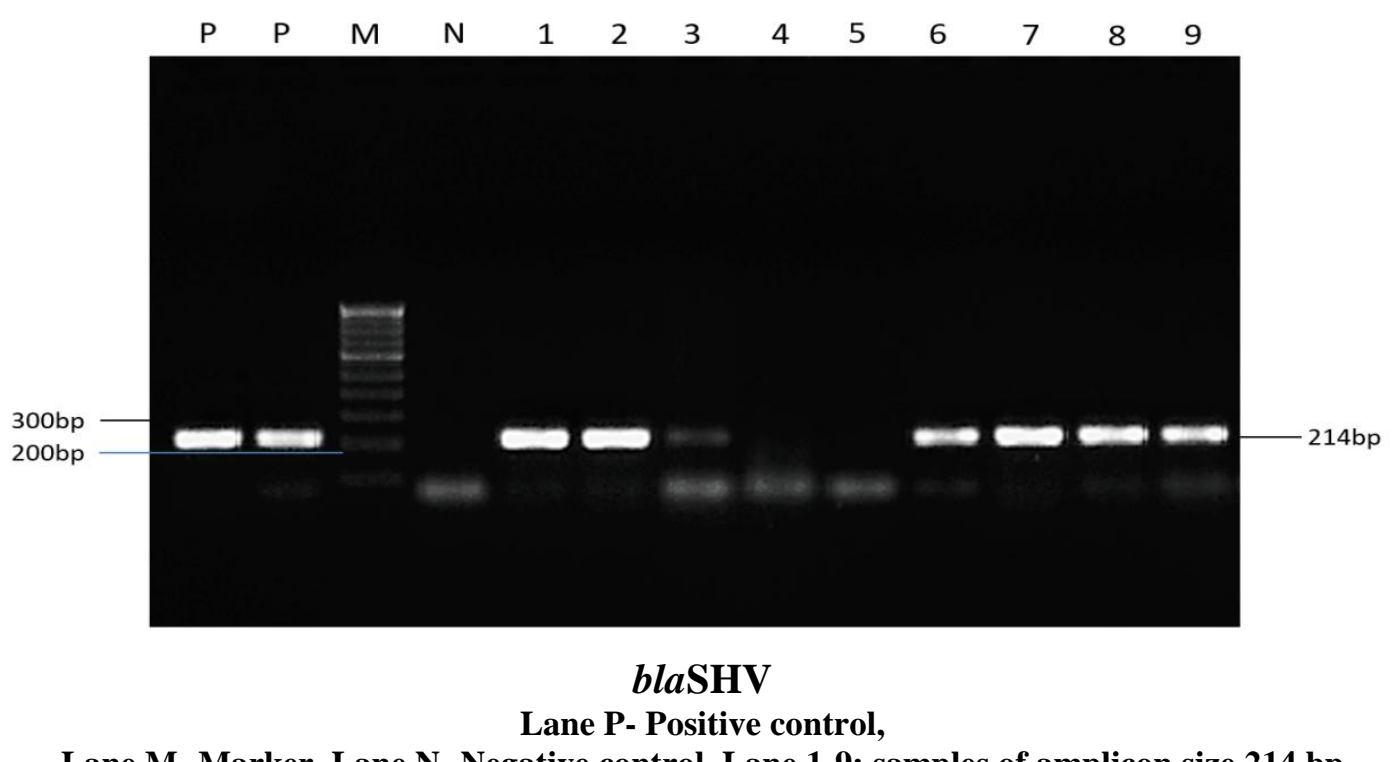

Lane M- Marker, Lane N- Negative control, Lane 1-9: samples of amplicon size 214 bp 


\section{Fig.7 PCR standardization for blaTEM}

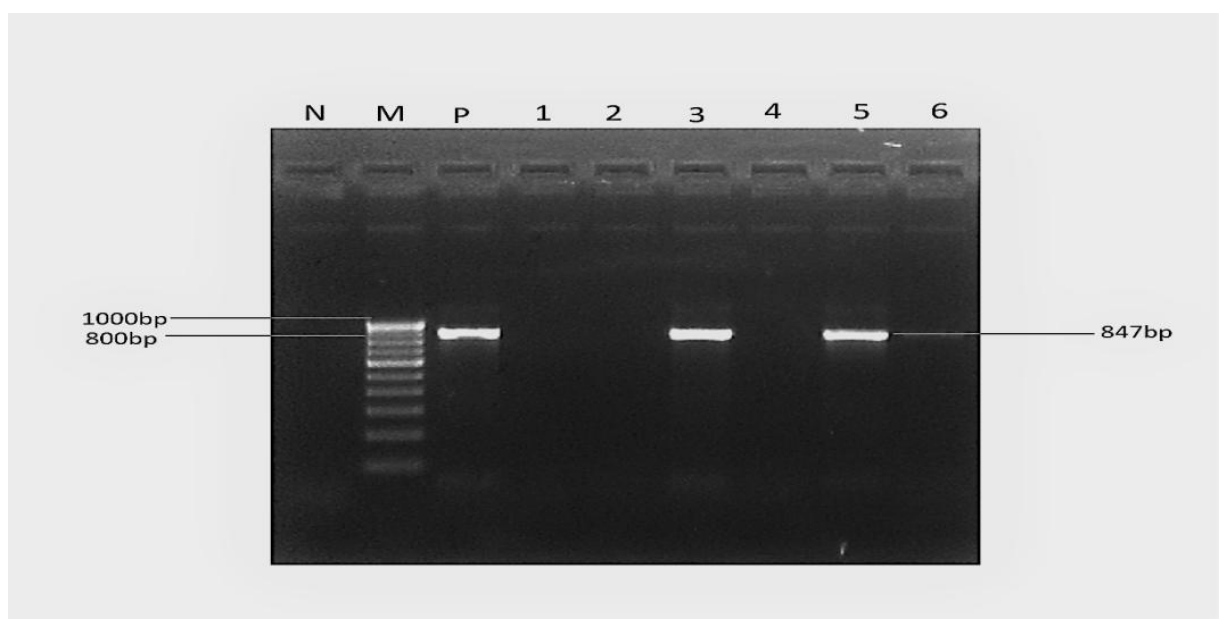

\section{bla TEM}

Lane N- Negative control, Lane M- Marker, Lane P- Positive control, Lane 1-6: samples of amplicon size 847 bp

One Salmonella isolate from raw milk sample was having all the three genes. blaCTX-M and blaSHV was together present in 3 Salmonella isolates. In contradictory, researchers like Elumalai et al., (2014) and Olesen et al., (2004) found higher blaTEM prevalence among Salmonella isolates but in the present study revealed blaSHV and blaCTX-M was found as more prominent gene among Salmonella isolates. This variation in the occurrence of gene is attributed to the geographical area where study has undertaken, sample size, type of sample and drugs used and its dosage in particular area. This higher prevalence of genes among both organisms is the indication of widespread of resistant genes among human and domestic animals in Wayanad district which is a matter of great importance. Strict measures should be taken to reduce the spread of this resistant gene among human and animal communities.

Thus the present study revealed the significant occurrence of ESBL producing E. coli and Salmonella spp. from raw milk samples. Presences of antibiotic resistance to third generation cephalosporins were detected among the organisms which can transmit to humans through milk. Resistant organisms in raw milk indicate indiscriminate use of antibiotics among food producing animals. Strict legislative measures have to be taken against this and to prevent further transmission of resistant pathogenic organisms to humans.

\section{Acknowledgement}

I would like to thank, Dean, College of Veterinary and Animal sciences, Pookode, KVASU and Staff and colleagues of Department of VPH, CVAS, Pookode for their valuable contribution to the present research work

\section{References}

Agarwal, R.K., Bhilegaonkar, K.N., Singh, D. K., Ashok, K. and Rathore, R.S. 2003. In: Laboratory manual for the isolation and identification of food borne pathogens. Indian Veterinary Research Institute, Izatnagar, Bareilly, India, 100p.

Ahmed, A.M., Nakano, H. and Shimamoto, T. 2004. The first characterization of Extended-spectrum $\quad \beta$-lactamase- 
producing Salmonella in Japan. $J$. Antimicrob. Chemother. 54, 283-284

Ali, A.A. and Abdelgadir, W.S. 2011. Incidence of Escherichia coli in raw cow's milk in Khartoum state. Br. J. Dairy Sci. 2, 23-26.

Bajpai, T., Pandey, M., Varma, M. and Bhatambare, G.S. 2017. Prevalence of TEM, SHV, and CTX-M BetaLactamase genes in the urinary isolates of a tertiary care hospital. Avicenna $J$. Med. 7, 12-16.

Barrow, G.I. and Feltham, R.K.A. 2003. Cowan and Steel's Manual for Identification of Medical Bacteria. $\left(3^{\text {rd }}\right.$ Ed) Cambridge press. 331p

Bej, A.K., Dicesare, J.L., Haff, L. and Atlas, R.M. 1991. Detection of Escherichia coli and Shigella spp. in water by using the polymerase chain reaction and gene probes for uid. Appl. Environ. Microbiol. 57, 1013-1017.

Botrel, M.A., Haenni, M., Morignat, E., Sulpice, P., Madec, J.Y. and Calavas, D. 2010. Distribution and antimicrobial resistance of clinical and subclinical mastitis pathogens in dairy cows in Rhône-Alpes, France. Foodborne Pathog. Dis. 7: 479-487.

Chye, F.Y., Abdullah, A. and Ayob, M.K. 2004. Bacteriological quality and safety of raw milk in Malaysia. Food Microbiol. 21: 535-541.

Elumalai, S., Muthu, G., Selvam, R.E.M. and Ramesh, S. 2014. Detection of TEM-, SHV-and CTX-M-type $\beta$-lactamase production among clinical isolates of Salmonella species. J. Med. Microbiol. 63: 962-967.

Galan, J.E., Ginocchio, C. and Costeas, P. 1992. Molecular and functional characterization of the Salmonella invasion gene invA: homology of invA to member of a new protein family. $J$. Bacteriol. 174: 4338-4349.

Junaidu, A.U., Salihu, M.D., Tambuwal, F.M.,
Magaji, A.A. and Jaafaru, S. 2011. Prevalence of mastitis in lactating cows in some selected commercial dairy farms in Sokoto metropolis. $A d v$. Appl. Sci. Res. 2: 290-294.

Karns, J.S., Van Kessel, J.S., McCluskey, B.J. and Perdue, M.L. 2005. Prevalence of Salmonella enterica in bulk tank milk from US dairies as determined by polymerase chain reaction. J. Dairy Sci. 88: 3475-3479.

Kaushik, P., Kumari, S., Bharti, S.K. and Dayal, S. 2014. Isolation and prevalence of Salmonella from chicken meat and cattle milk collected from local markets of Patna, India. Vet. Wld. 7: 62-65.

Kee, C.N.R.D. 2012. Bovine mastitis: an Asian perspective. Asian Journal of Animal and Veterinary Advances. 7: 454-476.

Kumar, R. and Prasad, A. 2010. Detection of E. coli and Staphylococcus in milk and milk products in and around Pantnagar. Vet. Wld. 3: 495-496.

Levy, S.B. 1997. Antibiotic resistance: an ecological imbalance. In Ciba Found Symp. 207: 1-9.

Murinda, S.E., L.T. Nguyen, H.M. Man and R.A. Almedia, 2004. Detection of sorbitol negative and sorbitol-positive shiga toxin-producing Escherichia coli, Listeria monocytogenes, Campylobacter jejuni and Salmonella species in dairy farm environments. Food-borne Pathogens and Disease, 1: 97-104.

Nagdeo, N.V., Kaore, N.M. and Thombare, V.R. 2012. Phenotypic methods for detection of various $\beta$-lactamases in Gram-negative clinical isolates: Need of the hour. Chron. Young Sci. 3: 292298.

Olesen, I., Hasman, H. and Møller Aarestrup, F. 2004. Prevalence of $\beta$-lactamases among ampicillin-resistant Escherichia 
coli and Salmonella isolated from food animals in Denmark. Microb. Drug Resist. 10: 334-340.

Olowe, O.A., Adewumi, O., Odewale, G., Ojurongbe, O. and Adefioye, O.J. 2015. Phenotypic and molecular characterisation of extended-spectrum beta-lactamase producing Escherichia coli obtained from animal fecal samples in Ado Ekiti, Nigeria. $J$. Environ. Public Hlth. 1: 1-7.

Owens, W.E., Ray, C.H., Watts, J.L., and Yancey, R.J. 1997. J. Dairy Sci. 80:313-317.

Radostits, O.M., Gay, C.C., Blood, D.C. and Hinchcliff, K.W. 2000. A textbook of the diseases of cattle, sheep, pigs, goats and horses. Vet. Med. 9: 13711441.

Rajeev, R., Gupta, M.K. and Singh, K.K. 2011. Study of bovine mastitis in different climatic conditions in Jharkhand, India. Vet. Wld. 4: 205-208.

Shrestha, S. and Bindari, Y.R. 2012. Prevalence of sub-clinical mastitis among dairy cattle in Bhaktapur District, Nepal. Int. J. Agric.Biosci. 1: 16-19.

Sumathi, B.R., Veeregowda, B.M. and Amitha, R.G. 2008. Prevalence and antibiogram profile of bacterial isolates from clinical bovine mastitis. Vet. Wld. 1: 237-238.

Tadesse, T. and Dabassa, A. 2012. Prevalence and antimicrobial resistance of Salmonella isolated from raw milk samples collected from Kersa district, Jimma Zone, Southwest Ethiopia. $J$. Med. Sci. 12: 224-228.

Thaker, H.C., Brahmbhatt, M.N. and Nayak, J.B. 2012. Study on occurrence and antibiogram pattern of Escherichia coli from raw milk samples in Anand, Gujarat, India. Vet. Wld. 5: 556-559.

Yang, B., Wang, Q., Cui, S., Wang, Y., Shi, C., Xia, X., Xi, M., Wang, X., Shi, X., Wang, D. and Zhang, Z. 2014. Characterization of extended-spectrum beta-lactamases-producing Salmonella strains isolated from retail foods in Shaanxi and Henan Province, China. Food Microbiol. 42: 14-18

Yazdi, M., Nazemi, A., Mirinargasi, M., Jafarpour, M., Sharifi, S.H. and Branch, T. 2012. Genotypic versus phenotypic methods to detect extended-spectrum beta-lactamases (ESBLs) in uropathogenic Escherichia coli. Ann. Biol. Res. 3: 2454-2458

\section{How to cite this article:}

Akarsh, K. L., Prejit, K. Asha, Jess Vergis, V. K. Vinod and Hema Persis Andrews. 2019. Occurrence and Characterization of Extended Spectrum $\beta$ - lactamase Producing E. coli and Salmonella spp. from Raw Milk Samples in Wayanad District, Kerala, India. Int.J.Curr.Microbiol.App.Sci. 8(12): 2089-2098. doi: https://doi.org/10.20546/ijcmas.2019.812.247 